\title{
Practical diagnosis and management of peripheral vertigo
}

\author{
Periferik vertigoya yönelik pratik tanı ve tedavi \\ Erdal Sakallı, ${ }^{1}$ Dastan Temirbekov, ${ }^{2}$ Cengiz Çelikyurt, ${ }^{2}$ Gamze Kıllı̧̧ \\ ${ }^{1}$ Department of Audiology, School of Health Sciences, Gelişim University, İstanbul, Turkey \\ ${ }^{2}$ Department of Otolaryngology, Safa Private Hospital, İstanbul, Turkey
}

\begin{abstract}
Objectives: This study aims to investigate the reliability of clinical diagnostic modalities of the patients with dizziness and the effectiveness of the vestibular rehabilitation therapy.

Patients and Methods: We examined the patients who were admitted to our hospital between February 2013 and June 2014 with complaints of dizziness and examined in the audio-vestibular laboratory. In the audio-vestibular laboratory, patients went through the following examinations: spontaneous nystagmus and gaze nystagmus, skew deviation, head impulse test, head-shaking nystagmus test, dynamic visual acuity test, Dix-Hallpike maneuver, supine roll test, Tandem Romberg test and Modified Clinical Test of Sensory Interaction and Balance. The patients with symptoms of pathology in the central nervous system were excluded from the study. Vestibular rehabilitation therapy was used depending on the clinical diagnosis of the patients. The patients were evaluated one year later to investigate the vestibular rehabilitation treatment outcomes.
\end{abstract}

Results: One hundred and four patients (35 males, 69 females) were found to be eligible for this study. Ninety-two (88.4\%) out of 104 patients got a final clinical diagnosis. The most common diagnoses were unilateral vestibulopathy and posterior canal benign positional paroxysmal vertigo, respectively. Although 12 patients (11.6\%) could not be diagnosed definitely, acute central pathologies were excluded in all of the patients. $75.96 \%$ out of 104 patients were relieved in 15 days, $94.23 \%$ in 30 days, $98.08 \%$ in 45 days, $99.04 \%$ in 60 days and it took 75 days for the rest of the patients. In the one year post-treatment interview, $83.2 \%$ of patients confirmed having benefits of the vestibular therapy and none of the patients experienced cerebral stroke.

Conclusion: The combined set of diagnostic tests performed in the audio-vestibular laboratory is reliable and sufficient. Vestibular rehabilitation is very effective in relieving the symptoms of peripheral vestibular dysfunction and increasing the quality of life of the patients with dizziness.

Keywords: Peripheral vertigo; vestibular rehabilitation; vestibulopathy; vestibular dysfunction.
$\ddot{O} Z$

Amaç: Bu çalışmada baş dönmesi olan hastaların tanısında kullandığımız klinik tanı yöntemlerinin güvenilirliği ve vestibüler rehabilitasyon tedavisinin etkinliği araştırıldı.

Hastalar ve Yöntemler: Şubat 2013 - Haziran 2014 tarihleri arasında hastanemize baş dönmesi nedeniyle başvuran ve odiyo-vestibüler laboratuvarda periferik vertigo tanısıyla tedavi edilen hastalar incelendi. Odiyo-vestibüler laboratuvarında hastalar şu muayenelerden geçti: spontan nistagmus ve bakışta (gaze) nistagmus, bakış yönünde kayma testi (skew deviation), baş itme testi, baş sallama nistagmus testi, dinamik görme keskinliği testi, Dix-Hallpike manevrası, sırt üstü yuvarlanma testi, Tandem Romberg testi ve modifiye denge duyusal etkileşimi klinik testi. Merkezi sinir sistemi patoloji semptomları olan hastalar çalışma dışı bırakıldı. Hastaların klinik tanısına göre vestibüler rehabilitasyon tedavisi yapıldı. Hastalar bir yıl sonra vestibüler rehabilitasyon tedavisinin sonuçlarını incelemek üzere değerlendirildi.

Bulgular: Yüz dört hasta (35 erkek, 69 kadın) bu çalışma için uygun bulundu. Yüz dört hastanın 92'sine (\%88.4) nihai klinik tanı konulabildi. En sık konulan tanılar sırasıyla tek taraflı vestibüler disfonksiyon ve posteriyor kanal benign pozisyonel paroksizmal vertigo idi. Her ne kadar on iki hastaya (\%11.6) kesin tanı konulamamış olsa da tüm hastalarda akut santral patoloji hariç tutuldu. Yüz dört hastanın \%75.96'sının tedavisi 15 gün, $\% 94.23$ 'ünün 30 gün, $\% 98.08$ 'inin 45 gün, $\% 99.04$ ünün 60 gün sürdü ve kalan hastaların tedavisinin sonlanması ise 75 günü buldu. Bir yıl sonra telefon görüşmesiyle yapılan değerlendirmede hastaların \%83.2'sinin vestibüler rehabilitasyon tedavisinden fayda gördüğü ve hiçbir hastada serebral inme gelişmediği öğrenildi.

Sonuç: Odiyo-vestibüler laboratuvarında kullanılan klinik testler serisi birlikte değerlendirildiğinde güvenilir ve yeterlidir. Vestibüler rehabilitasyon, periferik vestibüler disfonksiyon semptomlarının hafifletilmesinde ve baş dönmesi olan hastaların yaşam kalitesinin artırılmasında çok etkilidir.

Anahtar sözcükler: Periferik vertigo; vestibüler rehabilitasyon; vestibülopati; vestibüler disfonksiyon. 
Vertigo is the illusion of rotational movement of self or surroundings and one of the most frequent complaints of patients referred to the emergency department. ${ }^{[1]}$ Although the most common causes of vertigo and dizziness are benign, differential diagnosis must include potentially life-threatening central disease. Various clinical tests for differential diagnosis of vertigo have been investigated, but none reached adequate sensitivity and specificity to be used as a stand-alone test. Even neuroimaging tests (computed tomography and magnetic resonance imaging) that are not always readily available, are not reliable enough in the early period of central vertigo $(\mathrm{CV}) \cdot{ }^{[2]}$

Depending on their etiology and type, vestibular dysfunctions (VD) may be treated with physiotherapy, psychotherapy, pharmacotherapy and surgery and frequently patients with vertiginous complaints need combined therapy. ${ }^{[3]}$ The physiotherapeutic approach called vestibular rehabilitation (VR) is a low-cost and effective method in the treatment of almost all vestibular disorders.

The purpose of this trial is to demonstrate that peripheral vertigo (PV) can be safely diagnosed by using time consuming but easy-to-do series of clinical tests, and to investigate the effectiveness of VR therapy for vestibular disorders.

\section{PATIENTS AND METHODS}

This prospective, non-randomized study was conducted between February 2013 and June 2014. After obtaining a complete history and performing a full otolaryngologic and head and neck examination at the Ear Nose and Throat (ENT) polyclinic, otolaryngologists directed the patients presenting with complaints of vertigo or dizziness to the audio-vestibular laboratory (AVL). Patients with a preliminary diagnosis of vertigo were referred to the AVL staffed by an otolaryngologist, physiotherapist and an audiometrist.

One hundred and four patients ( 35 males, 69 females) enrolled in this study. The age ranged from 21 to 85 years (mean: 50 years). All patients accepted both the participation and the follow-up schedule. The patients also signed an informed consent form, which contained a comprehensive description of the procedures, the expected outcomes, and the possible side effects.

Every vertigo patient completed a detailed dizziness questionnaire (10-minute) upon arriving at the VR clinic, and then went through the following examinations concentrating on vertigo:
1. Spontaneous nystagmus and gaze nystagmus. ${ }^{[4]}$

2. Skew deviation. ${ }^{[5]}$

3. Head impulse test (HIT). ${ }^{[4,6]}$

4. Head-shaking nystagmus test. ${ }^{[4]}$

5. Dynamic visual acuity test (DVA). ${ }^{[4,7,8]}$

6. Dix-Hallpike maneuver. ${ }^{[4]}$

7. Supine head turn maneuver (Pagnini-McClure maneuver). ${ }^{[9]}$

8. Tandem Romberg test. ${ }^{[4]}$

9. Modified Clinical Test of Sensory Interaction and Balance (mCTSIB ). ${ }^{[10]}$

Frenzel goggles were used to observe nystagmus. The patients with symptoms of central, neurological degenerative or cerebellar disorders were referred to the neurologist and excluded from the study. Based on need, specialized tests like audiometry, tragal compression, pneumatic otoscopy, Tullio phenomenon, valsalva with pinched nostrils and closed glottis, were performed.

The otolaryngologist and the physiotherapist educated the patients about vestibular system, balance and VR using pictures and video clips and that the symptoms should be provoked to a tolerable point while doing exercises. Patients had been instructed to do exercises at home for two sessions per day, in the morning and evening, each session lasting 20 to 30 minutes.

Vestibular rehabilitation exercises ${ }^{[11]}$ were individualized taking the patient's age and physical status into account. A printout of exercises was given patients to be practised at home. Vestibular rehabilitation exercises were gradually increased in complexity as the patients go better. The Epley maneuver for posterior canal benign paroxysmal positional vertigo (BPPV) and the Lempert supine roll maneuver for horizontal canal BPPV were performed in every session. ${ }^{[12,13]}$ Patients were requested to quit their maladaptive postural adjustments (moving and turning slowly, en bloc turning and avoidance of head motion, staying at home never going out alone).

Patients visited the VR clinic every two weeks for assessment until symptoms were reported to be relieved in face-to-face interview. Dynamic visual acuity test was also used for the post-therapy assessment. Maintenance exercises were started when patients satisfactorily improved.

The patients were interviewed by telephone one year later and were asked if they experienced repeated vertigo attacks, cerebral stroke or any other illness. Patients were asked how much they benefited from VR treatment. 


\begin{tabular}{|lccccccc|}
\hline \multicolumn{7}{|c|}{ Table 1 } \\
\hline \multicolumn{7}{|c|}{ Distribution of 104} & chronic vertigo patients by age \\
\hline Range of the age & $21-29$ & $30-39$ & $40-49$ & $50-59$ & $60-69$ & $70-79$ & $80-85$ \\
\hline Patients (n) & 12 & 16 & 25 & 20 & 21 & 7 & 3 \\
\hline
\end{tabular}

\begin{tabular}{|lc|}
\hline \multicolumn{2}{|c|}{$\begin{array}{c}\text { Table } 2 \\
\text { Accompanying symptoms of chronic vertigo }\end{array}$} \\
\hline Symptoms & Number of patients \\
\hline Vertigo provoked by sudden or fast head movement & 47 \\
Vertigo on walking in crowd & 19 \\
Fear of height & 13 \\
Inability to get out of home alone and walk because of fear of vertigo & 8 \\
Fall & 6 \\
Inability to cross a street & 5 \\
Fear of falling & 3 \\
Vertigo on looking at vehicles passing by & 3 \\
Inability to climb stairs & 3 \\
Inability to take elevator & 2 \\
Vertigo on looking down over the railing of a high balcony & 2 \\
Tossing at sides of furniture while moving around at home & 2 \\
Vertigo on looking out of window & 2 \\
Vertigo on looking at water flowing out of valve & 1 \\
Vertigo on looking at moving parts of a machine & 1 \\
Vertigo provoked by moving rain wiper while driving & 1 \\
\hline
\end{tabular}

\section{RESULTS}

Distribution of 104 chronic vertigo patients is given in Table 1 . The time period since the onset of symptoms ranged from 3 months to 10 years (mean: 29 months).

Ninety-two out of 104 patients obtained a final clinical diagnosis. The patients' symptoms accompanying vertigo are listed in Table 2 . The most common diagnoses were unilateral vestibulopathy and posterior canal BPPV respectively (Table 3 ).

$75.96 \%$ out of 104 patients were relieved in 15 days, $94.23 \%$ in 30 days, $98.08 \%$ in 45 days, $99.04 \%$ in 60 days and $100 \%$ in 75 days (Table 4 ).

Out of 104 patients, 72 patients were interviewed about the vestibular therapy over the phone in one year,

\begin{tabular}{|lccc|}
\hline \multicolumn{4}{|c|}{ Table 3 } \\
& & \\
104 chronic vertigo patients with clinical diagnosis \\
\hline Final diagnosis & Male & Female & Total \\
\hline p BPPV & 8 & 20 & 28 \\
h BPPV & 1 & 3 & 4 \\
Unilateral vestibulopathy & 11 & 25 & 36 \\
Bilateral vestibulopathy & 5 & 6 & 11 \\
p BPPV and unilateral vestibulopathy & 5 & 6 & 11 \\
p BPPV and bilateral vestibulopathy & 2 & 0 & 2 \\
No diagnosis & 4 & 8 & 12 \\
\hline BPPV: Benign paroxysmal positional vertigo. & & & \\
\hline
\end{tabular}


Table 4

\begin{tabular}{|c|c|c|c|c|c|}
\hline Period of vestibular rehabilitation & 15 days & 30 days & 45 days & 60 days & 75 days \\
\hline Unilateral vestibulopathy & 36 & 10 & 2 & 1 & 1 \\
\hline Bilateral vestibulopathy & 11 & 4 & 1 & & \\
\hline p BPPV & 28 & 4 & 1 & 1 & \\
\hline h BPPV & 4 & & & & \\
\hline p BPPV and unilateral vestibulopathy & 11 & 3 & 2 & & \\
\hline p BPPV and bilateral vestibulopathy & 2 & & & & \\
\hline No diagnosis & 12 & 4 & & & \\
\hline Patients taking vest therapy sessions & 104 & 25 & 6 & 2 & 1 \\
\hline Patients relieved in each 15 day session & 79 & 19 & 4 & 1 & 1 \\
\hline Total percentage of patient relieved after each session & 75.96 & 94.23 & 98.08 & 99.04 & 100 \\
\hline
\end{tabular}

\begin{tabular}{|c|c|c|c|c|c|c|c|c|}
\hline \multicolumn{9}{|c|}{ Table 5} \\
\hline \multirow{3}{*}{ Self assessment } & \multicolumn{6}{|c|}{ Benefited } & \multirow{2}{*}{\multicolumn{2}{|c|}{ Not benefited }} \\
\hline & \multicolumn{2}{|c|}{ Complete } & \multicolumn{2}{|c|}{ Good } & \multicolumn{2}{|c|}{ Fair } & & \\
\hline & $\mathrm{n}$ & $\%$ & $\mathrm{n}$ & $\%$ & $\mathrm{n}$ & $\%$ & $\mathrm{n}$ & $\%$ \\
\hline Patients & 39 & 54.1 & 16 & 22.2 & 5 & 6.9 & 12 & 16.6 \\
\hline
\end{tabular}

31 patients were not connected, and one patient passed away (Table 5). A total of $83.2 \%$ of patients confirmed benefits of the VR.

\section{DISCUSSION}

The treatment of PV depends on the diagnosis which is basically derived from adequate patient assessment through a detailed history and examination by otolaryngologists interested in vertigo.

Differential diagnosis should be carried out primarily with pathologies of the central nervous system (CNS). Bedside predictors like the gaze test, HIT, Dix-Hallpike maneuver, DVA, Tandem Romberg test are usually easy to perform and essential to rule out patients with central vestibulopathies. ${ }^{[1]}$

There are dozens of tests described in the literature to distinguish PV from CV. However there is no single test with adequate sensitivity and specificity.

Spontaneous nystagmus in neutral gaze position is usually observed in all acute vestibular syndromes. Direction-changing nystagmus is pathognomonic of central pathology. Gaze-evoked nystagmus is also central in origin and causes include: a drug effect (sedatives, antiepileptics), alcohol, CNS tumors, and cerebellar degenerative syndromes. ${ }^{[4]}$

Cnyrim et al. ${ }^{[5]}$ investigated the usefulness of finding skew deviation, negative HIT, gaze-evoked nystagmus, impaired vertical smooth pursuit and deviation of subjective visual vertical and found that when all five signs were combined, the sensitivity and specificity in diagnosing central vertigo increased to $92 \%$.

Vanni et al. ${ }^{[1]}$ suggested a four-step bedside algorithm for differential diagnosis of acute vertigo (spontaneous nystagmus, direction, HIT, standing).

The dynamic visual acuity test is a useful indicator of the vestibulo-ocular reflex and can be used to determine VD. It can also be used for post-therapy assessment to measure the therapeutic response in patients reporting improvement of vertigo and accompanying symptoms. Studies demonstrate the reliability and validity of DVA to identify the side of vestibular dysfunction in both unilateral and bilateral vestibular pathologies ${ }^{[7]}$ and that VR improves DVA in subjects with vestibular dysfunction. ${ }^{[8,14,15]}$

The Dix-Hallpike maneuver is generally considered the gold standard test for the diagnosis of posterior canal BPPV. ${ }^{[16]}$ The Epley and Semont maneuvers 
are effective and best known repositioning methods for posterior canal involvement. ${ }^{[16]}$ Supine head turn maneuver (Pagnini-McClure maneuver) is the most commonly accepted criterion for the diagnosis of lateral canal BPPV. ${ }^{[16]}$

Although lateral canal BPPV is a more resistant type of BPPV than posterior canal BPPV, repositioning maneuvers like the Lempert roll, forced prolonged positioning and Gufoni maneuver, are effectively used to treat lateral canal BPPV. The Lempert roll appears to be the most commonly used technique in the literature and we also use this maneuver to treat lateral canal PBBV patients. ${ }^{[9,13,16]}$ In our practice in general we do not need any other technique except Dix-Halpike and supine head turn tests as diagnostic and Epley and Lempert maneuvers as treatment methods of BPPV.

The Romberg test is a test of the proprioception, which requires healthy function of the spinal cord. It is used to investigate the cause of motor coordination of either cerebellar or sensory origin. The tandem stance makes the Romberg test sensitive to vestibular deficits. ${ }^{[4]}$

The mCTSIB test is designed to assess how well a dizzy patient is using each of sensory inputs when one or more sensory systems (i.e., vision, somatosensory and vestibular) are compromised. Poor performance on this test suggests the need for multisensory training. ${ }^{[10]}$

Patients with vertigo usually do not have to go through costly tests to confirm the diagnosis at a sophisticated laboratory. A diagnosis was not clearly obtained in 11.5 percent of our patients. None of them presented with central pathologies in one year followup. In cases with no clear diagnosis, a trial of VR is worth to do while follow-up visits and investigations continue, because VRT succeeded to relieve those patients' symptoms.

Detailed information about the vestibular system and what is happening during episodes of vertigo are very effective in demystifying vertigo and relieving patients from the resulting anxiety.

Patients with vertigo often present with various accompanying symptoms, resulting in several physical and functional limitations that affect their daily activities and even their jobs. Some patients dramatically reduce their mobility and have maladaptive postural adjustments to avoid vertigo and associated symptoms (Table 5). In this study, vestibular rehabilitation therapy was a highly effective therapeutic approach for adults having vestibular deficits to get relief from their symptoms. The evidence in the literature supports the effectiveness of vestibular rehabilitation. ${ }^{[17,18]}$
The patients' ages and time period since the symptoms started did not affect the outcome of VR. Reports demonstrate that vestibular exercises are generally effective regardless of the patient's age and duration of symptoms. ${ }^{[8,19]}$

The patients with vestibulopathy caused by ototoxicity should be discouraged from driving at nighttime or while it is raining until VR has been completed. It is possible that a short period of vertigo provoked by moving rain wiper or water flowing down the front window or diminished visual input during nighttime may lead to a traffic accident. ${ }^{[19,20]}$

Otolaryngologists may want to handle the treatment themselves. But it is too time consuming for otolaryngologists to conduct VR. An AVL located next to ENT polyclinic in the same hospital will be advantageous for otolaryngologists to take part in VR and to staff the AVL.

In conclusion, the set of diagnostic tests which are validated in the literature and performed in the our AVL are time consuming but easy to perform and reliable in combination. Furthermore it is cost-effective and simple to organize an AVL for ENT clinics. In this study, VR was assessed to be very effective in relieving the symptoms of peripheral vestibular dysfunction. Therefore vertigo patients should be encouraged to take VR which is safe and effective to relieve vertigo associated symptoms resulting limitations in mobility and decreasing the quality of life.

\section{Declaration of conflicting interests}

The authors declared no conflicts of interest with respect to the authorship and/or publication of this article.

\section{Funding}

The authors received no financial support for the research and/or authorship of this article.

\section{REFERENCES}

1. Vanni S, Pecci R, Casati C, Moroni F, Risso M, Ottaviani M, et al. STANDING, a four-step bedside algorithm for differential diagnosis of acute vertigo in the Emergency Department. Acta Otorhinolaryngol Ital 2014;34:419-26.

2. Kattah JC, Talkad AV, Wang DZ, Hsieh YH, Newman-Toker DE. HINTS to diagnose stroke in the acute vestibular syndrome: three-step bedside oculomotor examination more sensitive than early MRI diffusionweighted imaging. Stroke 2009;40:3504-10.

3. Tsukamoto HF, Costa Vde S, Silva RA Junior, Pelosi GG, Marchiori LL, Vaz CR, et al. Effectiveness of a Vestibular Rehabilitation Protocol to Improve the Health-Related 
Quality of Life and Postural Balance in Patients with Vertigo. Int Arch Otorhinolaryngol 2015;19:238-47.

4. Goebel JA. The ten-minute examination of the dizzy patient. Semin Neurol 2001;21:391-8.

5. Cnyrim CD, Newman-Toker D, Karch C, Brandt T, Strupp M. Bedside differentiation of vestibular neuritis from central “vestibular pseudoneuritis". J Neurol Neurosurg Psychiatry 2008;79:458-60.

6. MacDougall HG, Weber KP, McGarvie LA, Halmagyi GM, Curthoys IS. The video head impulse test: diagnostic accuracy in peripheral vestibulopathy. Neurology 2009;73:1134-41.

7. Herdman SJ, Schubert MC, Das VE, Tusa RJ. Recovery of dynamic visual acuity in unilateral vestibular hypofunction. Arch Otolaryngol Head Neck Surg 2003;129:819-24.

8. Herdman SJ, Hall CD, Schubert MC, Das VE, Tusa RJ. Recovery of dynamic visual acuity in bilateral vestibular hypofunction. Arch Otolaryngol Head Neck Surg 2007;133:383-9.

9. Chu LC, Yang CC, Tsai HT, Lin HC. A simple algorithm for treating horizontal benign paroxysmal positional vertigo. Otol Neurotol 2014;35:1621-5.

10. Horn LB, Rice T, Stoskus JL, Lambert KH, Dannenbaum E, Scherer MR. Measurement Characteristics and Clinical Utility of the Clinical Test of Sensory Interaction on Balance (CTSIB) and Modified CTSIB in Individuals With Vestibular Dysfunction. Arch Phys Med Rehabil 2015;96:1747-8.
11. Desmond A. Vestibular Function: Evaluation and Treatment. New York: Thieme Medical Publishers Inc.; 2004.

12. Braschi E, Ross D, Korownyk C. Evaluating the Epley maneuver. Can Fam Physician 2015;61:878.

13. Lempert $T$, Tiel-Wilck K. A positional maneuver for treatment of horizontal-canal benign positional vertigo. Laryngoscope 1996;106:476-8.

14. Schubert MC, Migliaccio AA, Clendaniel RA, Allak A, Carey JP. Mechanism of dynamic visual acuity recovery with vestibular rehabilitation. Arch Phys Med Rehabil 2008;89:500-7.

15. Herdman SJ, Schubert MC, Tusa RJ. Role of central preprogramming in dynamic visual acuity with vestibular loss. Arch Otolaryngol Head Neck Surg 2001;127:1205-10.

16. Nguyen-Huynh AT. Evidence-based practice: management of vertigo. Otolaryngol Clin North Am 2012;45:925-40.

17. Hillier SL, McDonnell M. Vestibular rehabilitation for unilateral peripheral vestibular dysfunction. Cochrane Database Syst Rev 2011 Feb 16:CD005397.

18. Herdman SJ, editor. Vestibular Rehabilitation. 3rd ed. Philadelphia: F.A. Davis Co.; 2007.

19. Shepard NT, Telian SA, Smith-Wheelock M, Raj A. Vestibular and balance rehabilitation therapy. Ann Otol Rhinol Laryngol 1993;102:198-205.

20. Han IB, Song HS, Kim JS. Vestibular rehabilitation therapy: review of indications, mechanisms, and key exercises. Clin Neurol 2011;7:184-96. 